\title{
Pregnancy outcomes after chemotherapy for trophoblastic neoplasia
}

\author{
Mila Trementosa Garcia ${ }^{1 *}$, Lawrence Hsu Lin $^{1}$, KoJ Fushida ${ }^{1}$, Rossana Pulcinel Vieira Francisco ${ }^{1}$, Marcelo Zugaib ${ }^{1}$ \\ 'Division of Obstetrics, Department of Gynecology and Obstetrics, Faculdade de Medicina da Universidade de São Paulo (FMUSP), São Paulo, SP, Brazil
}

Study conducted at the Department of Gynecology and Obstetrics, Faculdade de Medicina da Universidade de São Paulo (FMUSP), São Paulo, SP, Brazil

Article received: $10 / 21 / 2015$ Accepted for publication: 1/9/2016

*Correspondence: Address: Av. Dr. Éneas de Carvalho Aguiar, 255

São Paulo, SP - Brazil

Postal code: 05403-000 mila.trementosa@gmail.com

http://dx.doi.org/10.1590/1806-9282.62.09.837

\section{SUMMARY}

Introduction: The successful development of chemotherapy enabled a fertilitysparing treatment for patients with trophoblastic neoplasia. After disease remission, the outcome of a subsequent pregnancy becomes a great concern for these women.

Objective: To analyze existing studies in the literature that describe the reproductive outcomes of patients with trophoblastic neoplasia treated with chemotherapy.

Method: Systematic review was performed searching for articles on Medline/ Pubmed, Lilacs and Cochrane Library databases, using the terms "gestational trophoblastic disease" and "pregnancy outcome".

Results: A total of 18 articles were included. No evidence of decreased fertility after chemotherapy for trophoblastic neoplasia was observed. The abortion rates in patients who conceived within 6 months after chemotherapy was higher compared to those who waited longer. Some studies showed increased rates of stillbirth and repeat hydatidiform moles. Only one work showed increased congenital abnormalities.

Conclusion: The pregnancies conceived after chemotherapy for trophoblastic neoplasia should be followed with clinical surveillance due to higher rates of some pregnancy complications. However, studies in the literature provide reassuring data about reproductive outcomes of these patients.

Keywords: gestational trophoblastic disease, hydatidiform mole, choriocarcinoma, chemotherapy, pregnancy, fertility.

\section{INTRODUCTION}

Gestational trophoblastic disease is a group of placental disorders that include hydatidiform mole, invasive mole, choriocarcinoma, placental site trophoblastic tumor and epithelioid trophoblastic tumor. Hydatidiform mole is the most common form of trophoblastic disease, and is considered a benign condition that may develop into other malignant forms, referred indistinctly as gestational trophoblastic neoplasia. ${ }^{1,2}$

The incidence of hydatidiform mole varies in different populations, affecting 1:1,000 pregnancies in Europe and the United States, while in Asian countries the incidence may reach up to two cases in every 1,000 pregnancies. ${ }^{2}$ In Brazil, there is no official database for gestational tropho- blastic disease. A large Brazilian epidemiological study showed the occurrence of 5,250 cases of gestational trophoblastic disease in ten reference centers over the course of 11 years, which can be translated into 477 new cases per year. ${ }^{3}$

The diagnosis of hydatidiform mole is based on clinical symptoms, serum level of human chorionic gonadotropin (hCG), ultrasound scans and histopathological analysis of the material obtained after uterine evacuation. Hydatidiform mole is characterized into complete and partial mole according to clinical, histological and genetic features. In general, complete moles are generated by the fertilization of an empty oocyte by a sperm that 
duplicates its genetic material or by two spermatozoa, giving rise to an androgenetic diploid conception with intense trophoblastic hyperplasia and diffuse hydropic villi. In contrast, the partial mole originates from dispermy, with fertilization of an oocyte by two spermatozoa, producing a triploid pregnancy, with focal histological abnormalities. ${ }^{1,2,4}$

About $15 \%$ of patients with complete moles and less than $5 \%$ of those with partial moles develop gestational trophoblastic neoplasia, therefore, the monitoring of these women is fundamental to enable early detection of post-molar disease. The persistence of raised hCG levels and abnormal ultrasound imaging after uterine evacuation leads to the diagnosis of trophoblastic neoplasia, and in some cases metastasis may also be present. ${ }^{1,2}$

There is a choice between chemotherapy and/or surgery in the treatment of trophoblastic neoplasia, depending on staging, risk classification and reproductive desire. Patients with trophoblastic neoplasia are classified by the presence of risk factors according to the International Federation of Gynecology and Obstetrics' (FIGO) prognostic score (2002). Patients with a score from 0 to 6 are classified as having low-risk disease, receiving a single chemotherapy agent, whereas those with a score of 7 or more are considered as high-risk and benefit from receiving combination chemotherapy. ${ }^{2}$

More than $90 \%$ of patients with trophoblastic neoplasia undergo successful treatment with chemotherapy. ${ }^{2}$ Thus, an additional concern is related to their reproductive future. A study by Matsui et al. (1997) showed that $46.8 \%$ of patients using etoposide in the treatment of trophoblastic neoplasia had impaired ovarian function. ${ }^{5}$ Cytotoxic drugs are potentially mutagenic and teratogenic, so there is also a concern about the adverse effects of the subsequent pregnancy. For example, methotrexate, which is used as a chemotherapy agent, inhibits the metabolism of folic acid, an essential vitamin in fetal development. $^{6}$

In this review, we analyzed the studies existing in the literature that describe the reproductive future of patients with trophoblastic neoplasia treated with chemotherapy.

\section{Method}

The search was carried out by two independent researchers without any language restrictions in the following databases: Medline/Pubmed, Lilacs and the Cochrane Library. The keywords in Medline used in the searches (obtained using the Medical Subject Headings - MeSH) were "gestational trophoblastic disease" and "pregnancy outcome".
The inclusion criteria used in this review were: studies that evaluated gestational rate and outcomes after chemotherapy treatment for gestational trophoblastic disease. There was no restriction on the time interval between treatment and pregnancy. All articles were written in English or Portuguese.

After reading the articles, the references of interest from the original studies were also included.

In the initial search, 163 articles were found, with 26 articles selected by reading the title and abstracts after being reviewed by two independent researchers. Eight articles were excluded because they related to case reports (two studies), articles written in Chinese, the same case series reported by another study, gestational trophoblastic neoplasia concomitant with current pregnancy, gestational prognosis after prophylactic chemotherapy during molar evacuation, pregnancy after chemotherapy associated with partial uterine resection and after uterine perforation. At last, 18 articles were included in this review. The flow diagram for the selection of the articles can be found in Figure 1. No articles were found in the search on Cochrane and Lilacs.

\section{RESULTS}

The results of this study are summarized in Table 1, with the number of patients in each article included, as well as the number of pregnancies and their outcomes.

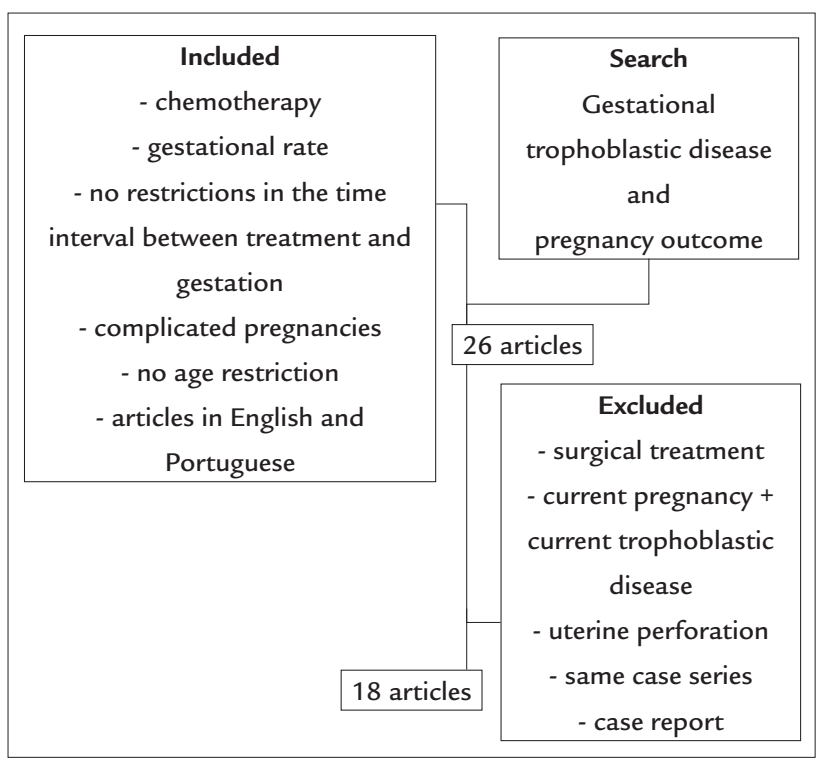

FIGURE 1 Search mechanism and algorithm for selection of articles for the review. 
Fertility

The articles did not show decreased fertility rates after treatment of the trophoblastic disease with chemotherapy. $^{6-23}$

Time to pregnancy conception after the end of chemotherapy Studies comparing pregnancies which were conceived within 6 months of the end of chemotherapy with those occurring after this period showed a higher spontaneous miscarriage rate in those who waited for a shorter time. Matsui et al. (2004) noted that the incidence of miscarriage, stillbirth and mole was higher in those conceiving within 6 months of the completion of chemotherapy compared to those who waited 1 year. ${ }^{17}$ Matsui et al. (2002) and Braga et al. (2009) also found that the incidence of miscarriage was higher in patients who became pregnant within 6 months. ${ }^{13,20}$ Lan et al. (2001) noted that patients presented a higher miscarriage rate when waiting $6.5 \pm 3.75$

TABLE 1 Pregnancy outcomes of women after receiving chemotherapy for gestational trophoblastic neoplasia.

\begin{tabular}{|c|c|c|c|c|c|c|c|c|}
\hline Study & $\begin{array}{l}\text { Patient } \\
\text { (n) }\end{array}$ & $\begin{array}{l}\text { Preg- } \\
\text { nancy }(n)\end{array}$ & $\begin{array}{l}\text { Term } \\
{[n(\%)]}\end{array}$ & $\begin{array}{l}\text { Stillbirth } \\
\text { [n (\%)] }\end{array}$ & $\begin{array}{l}\text { Abortion and } \\
\text { ectopic [n (\%)] }\end{array}$ & $\begin{array}{l}\text { Repeat mole } \\
{[n(\%)]}\end{array}$ & $\begin{array}{l}\text { Preterm } \\
\text { [n (\%)] }\end{array}$ & $\begin{array}{l}\text { Malformations } \\
\text { [n (\%)] }\end{array}$ \\
\hline $\begin{array}{l}\text { Rustin et al., } \\
1984^{7}\end{array}$ & 245 & 368 & $273(74.1)$ & $8(2.1)$ & $55(15)$ & - & $5(1.3)$ & $2(0.5)^{* *}$ \\
\hline $\begin{array}{l}\text { Song et al., } \\
1988^{8}\end{array}$ & 205 & 355 & $279(78.6)$ & $5(1.4)$ & $28(8)$ & - & $20(6.7)$ & $3(1)^{*}$ \\
\hline $\begin{array}{l}\text { Kim et al., } \\
1998^{9}\end{array}$ & 517 & 115 & $89(77.4)$ & $1(0.9)$ & $17(15)$ & $5(4.3)$ & $3(2.6)$ & $3(3.2)^{*}$ \\
\hline $\begin{array}{l}\text { Woolas et } \\
\text { al., } 1998^{6}\end{array}$ & 680 & 1,313 & $\begin{array}{l}1,000 \\
(76.2)\end{array}$ & $19(1.4)$ & $190(14.5)$ & $18(1.4)$ & - & $18(1.7)^{*}$ \\
\hline $\begin{array}{l}\text { Tuncer et al., } \\
1999^{10}\end{array}$ & 43 & 29 & $22(75.9)$ & - & $3(10.3)$ & $1(3.4)$ & $3(10.3)$ & $1(4.1)^{*}$ \\
\hline $\begin{array}{l}\text { Amr et al., } \\
1999^{11}\end{array}$ & 42 & 120 & $94(78.3)$ & $3(2.5)$ & $8(6.8)$ & - & $15(12.5)$ & - \\
\hline $\begin{array}{l}\text { Lan et al., } \\
2001^{12}\end{array}$ & 22 & 22 & $9(40.9)$ & $1(4.5)$ & $1(4.5)$ & $1(4.5)$ & $1(4.5)$ & - \\
\hline $\begin{array}{l}\text { Blagden et } \\
\text { al., } 2002^{14}\end{array}$ & 1,532 & 230 & $164(71)$ & $2(1)$ & $26(11)$ & $3(1.3)$ & - & $3(1.3)^{* *}$ \\
\hline $\begin{array}{l}\text { Garner et al., } \\
2002^{15}\end{array}$ & - & 581 & $393(67.6)$ & $9(1.5)$ & $106(18)$ & $8(1.4)$ & $35(6)$ & $10(2.3)^{*}$ \\
\hline $\begin{array}{l}\text { Matsui et al., } \\
2002^{13}\end{array}$ & 129 & 243 & $169(69.5)$ & $2(0.8)$ & $27(11.1)$ & $5(2.1)$ & $5(2.1)$ & - \\
\hline $\begin{array}{l}\text { Lok et al., } \\
2003^{16}\end{array}$ & 50 & 21 & $16(76)$ & - & $2(9)$ & - & $2(9)$ & $2(11)^{*}$ \\
\hline $\begin{array}{l}\text { Matsui et al., } \\
2004^{17}\end{array}$ & 137 & 258 & $180(69.8)$ & $3(1.2)$ & $29(11.2)$ & $5(1.9)$ & $5(1.9)$ & - \\
\hline $\begin{array}{l}\text { Goto et al., } \\
2004^{18}\end{array}$ & 50 & 43 & $34(79)$ & 0 & $4(9.3)$ & 0 & 0 & $3(8.8)^{*}$ \\
\hline $\begin{array}{l}\text { Garrett et } \\
\text { al., } 2008^{19}\end{array}$ & - & 631 & $422(66.9)$ & $9(1.4)$ & $7(1.1)$ & $9(1.4)$ & $42(6.7)$ & $10(2.1)^{*}$ \\
\hline $\begin{array}{l}\text { Braga et al., } \\
2009^{20}\end{array}$ & - & 252 & $172(68.2)$ & $2(0.8)$ & $42(16)$ & $7(2.8)$ & $6(2.4)$ & $6(2.4)^{* *}$ \\
\hline $\begin{array}{l}\text { Williams et } \\
\text { al., 2014 }\end{array}$ & 1,204 & 255 & $174(68.2)$ & $2(0.8)$ & $34(13.4)$ & $3(1.4)$ & $14(5.4)$ & - \\
\hline Total & & 4,836 & $3,490(72)$ & $66(1.4)$ & $579(12)$ & 65 (1.6) & $156(4.7)$ & $89(2.3) * *$ \\
\hline
\end{tabular}

*Number of malformations / delivery; ** number of malformations / pregnancy. 
months to conceive, while those who had an uneventful pregnancy showed an interval of $9.78 \pm 2.22$ months between chemotherapy and pregnancy. ${ }^{12}$

\section{Single and multi agent chemotherapy}

Blagden et al. (2002) compared the pregnancy rates among women who conceived within a year of chemotherapy treatment with single or combined agent. The conception rate was higher in the single agent group. It was also noted that the miscarriage rate in the combination chemotherapy group was higher than the group treated with single agent. There was no difference in the rate of congenital anomalies, which was similar to the general population. ${ }^{14}$ However, Williams et al. (2014) compared the groups treated with single and combined agents and found no significant increase in the risk of miscarriage, ectopic pregnancy, repeat molar pregnancy or stillbirth, not even after comparing with the general population of the United Kingdom. ${ }^{21}$ Woolas et al. (1998) and Braga et al. (2008) also found no difference in the groups with single and combination chemotherapy. ${ }^{6,20}$

\section{Repeat molar pregnancy}

Woolas et al. (1998), Kim et al. (1998) and Lan et al. (2001) observed an increase in new molar pregnancy compared to the general population while analyzing the influence of chemotherapy on the reproductive future of patients with trophoblastic neoplasia. ${ }^{6,9,12}$ Matsui et al. (2002) showed a molar pregnancy recurrance rate that was seven times higher than the general population. ${ }^{13}$

\section{Higher stillborn rate}

Woolas et al. (1998), Garner et al. (2002), Garrett et al. (2008) and Vargas (2014) noted a higher stillbirth rate in patients treated with chemotherapy for gestational trophoblastic disease compared to the general population. , $^{6,15,19,22}$

\section{Higher malformation rate}

Only the study by Goto et al. (2004), which assessed choriocarcinoma patients treated with combination chemotherapy, noted a higher incidence of congenital anomalies. ${ }^{18}$

\section{Discussion}

The high cure rates of trophoblastic neoplasia after chemotherapy have enabled those patients to have a chance to concieve after the completion of the treatment. In the mid-1960s the mortality rate was $90 \%$, whereas the current survival rate is 90 to $95 \% .{ }^{19}$ How- ever, due to the potential adverse effects of chemotherapeutic agents, the reproductive success rates as well as gestational complications have become a concern for these women.

The number of studies in the literature regarding this theme is still small. In general, most of them monitor the reproductive rates up to the first year after the end of treatment and the outcome of these pregnancies. All of studies found were retrospective.

The studies point out that there is no change in fertility. Most of the patients who wish to conceive end up doing so successfully. However, not all of the studies take into account the patients's desire to conceive.

It is advisable for patients to use birth control for at least 1 year after chemotherapy with negative hCG levels in order to enable them to safely become pregnant, since this is the time period when most relapses occur. The higher rate of miscarriage in the first 6 months after the end of treatment shown in the literature stresses the importance of not become pregnant around this period. ${ }^{12,13,17,20}$ In women who already experienced a failed pregnancy, another unsuccessful pregnancy can lead to negative psychological impact.

Four articles showed a higher prevalence of stillbirths in comparison to the general population. ${ }^{6,15,19,22}$ However, the etiology of this phenomena is still unknown, and it is important to increase clinical surveillance in these pregnancies.

Sebire et al. (2003) have shown a 20-fold increase chance ( 1 in 55 pregnancies) of another molar pregnancy in patients with prior hydatidiform mole. ${ }^{24}$ In this review, four studies showed an increased chance of a repeat hydatidiform mole in patients who underwent chemotherapy for gestational trophoblastic neoplasia. ${ }^{6,9,12,13}$ This event does not seem to be associated with chemotherapy itself, as the risk of presenting with another hydatidiform mole is higher even in patients with spontaneous regression of molar disease.

Only one study out of the four that compared single and combined agents found a difference between the two groups; showing that the conception rate was higher in the single agent group, and the miscarriage rate was higher in the combination group. ${ }^{14}$ The other three articles did not find any difference between the groups in relation to ectopic pregnancy, second molar pregnancy, miscarriage or stillbirth. ${ }^{6,20,21}$

Trophoblastic disease affects women, especially in the age group of 20 to 30 years. The data collected in the literature presents a small sample of studies. Nevertheless, 
the results are homogeneous and comforting for those patients desiring motherhood. More studies with larger samples are necessary to ensure safer monitoring of patients with trophoblastic neoplasia who underwent chemotherapy.

\section{Conclusion}

The introduction of chemotherapy has changed the prognosis of patients with gestational trophoblastic neoplasia. Despite the new concern being the preservation of fertility, the studies did not show a decrease in fertility. The data is reassuring regarding pregnancies following chemotherapy. However, greater attention should be given to these patients, especially those who conceive within 6 months of treatment.

\section{Resumo}

Futuro reprodutivo após tratamento quimioterápico da neoplasia trofoblástica

Introdução: o sucesso do desenvolvimento da quimioterapia no tratamento da neoplasia trofoblástica proporcionou a possibilidade de conservação da fertilidade das pacientes, tornando o futuro reprodutivo uma nova preocupação após a remissão da doença.

Objetivo: analisar os estudos existentes na literatura que descrevem o futuro reprodutivo de pacientes com neoplasia trofoblástica tratadas com quimioterapia.

Método: revisão sistemática que buscou artigos nas bases de dados Medline/Pubmed, Lilacs e Biblioteca Cochrane, utilizando as palavras-chave "gestational trophoblastic disease" e "pregnancy outcome".

Resultados: foram selecionados 18 artigos de acordo com critérios de inclusão e exclusão. Não foi observada diminuição da fertilidade após a quimioterapia para neoplasia trofoblástica. Pacientes que engravidaram até 6 meses do término da quimioterapia apresentaram maiores taxas de abortamento quando comparadas às que esperaram mais de 6 meses. Alguns artigos encontraram maiores taxas de natimorto e nova mola hidatiforme. Apenas um estudo mostrou aumento da taxa de malformação.

Conclusão: as gestações subsequentes à neoplasia trofoblástica devem ser acompanhadas com vigilância clínica em decorrência da maior taxa de complicações na gestação, principalmente nas mulheres que engravidam até 6 meses após o término da quimioterapia. No entanto, os dados encontrados nos estudos tranquilizam quanto ao futuro reprodutivo dessas pacientes.
Palavras-chave: doença trofoblástica gestacional, mola hidatiforme, coriocarcinoma, quimioterapia, gravidez, fertilidade.

\section{REFERENCES}

1. Seckl MJ, Sebire NJ, Fisher RA, Golfier F, Massuger L, Sessa C; ESMO Guidelines Working Group. Gestational trophoblastic disease: ESMO Clinical Practice Guidelines for diagnosis, treatment and follow-up. Ann Oncol. 2013; 24(Suppl 6):vi39-50.

2. Ngan HY, Seckl MJ, Berkowitz RS, Xiang Y, Golfier F, Sekharan PK, et al. Update on the diagnosis and management of gestational trophoblastic disease. Int J Gynaecol Obstet. 2015; 131(Suppl 2):S123-6.

3. Braga A, Uberti EM, Fajardo Mdo C, Viggiano M, Sun SY, Grillo BM, et al. Epidemiological report on the treatment of patients with gestational trophoblastic disease in 10 Brazilian referral centers: results after 12 years since International FIGO 2000 Consensus. J Reprod Med. 2014; 59(5-6):241-7.

4. Seckl MJ, Sebire NJ, Berkowitz RS. Gestational trophoblastic disease. Lancet. 2010; 376(9742):717-29.

5. Matsui H, Seki K, Sekiya S, Takamizawa H. Reproductive status in GTD treated with etoposide. J Reprod Med. 1997; 42(2):104-10.

6. Woolas RP, Bower M, Newlands ES, Seckl M, Short D, Holden L. Influence of chemotherapy for gestational trophoblastic disease on subsequent pregnancy outcome. Br J Obstet Gynaecol. 1998; 105(9):1032-5.

7. Rustin GJ, Booth M, Dent J, Salt S, Rustin F, Bagshawe KD. Pregnancy after cytotoxic chemotherapy for gestational trophoblastic tumours. Br Med J (Clin Res Ed). 1984; 288(6411):103-6.

8. Song HZ, Wu PC, Wang YE, Yang XY, Dong SY. Pregnancy outcomes after successful chemotherapy for choriocarcinoma and invasive mole: long-term follow-up. Am J Obstet Gynecol. 1988; 158(3 Pt 1):538-45.

9. Kim JH, Park DC, Bae SN, Namkoong SE, Kim SJ. Subsequent reproductive experience after treatment for gestational trophoblastic disease. Gynecol Oncol. 1998; 71(1):108-12.

10. Tuncer ZS, Bernstein MR, Goldstein DP, Berkowitz RS. Outcome of pregnancies occurring before completion of human chorionic gonadotropin follow-up in patients with persistent gestational trophoblastic tumor. Gynecol Oncol. 1999; 73(3):345-7.

11. Amr MF. Return of fertility after successful chemotherapy treatment of gestational trophoblastic tumors. Int J Fertil Womens Med. 1999; 44(3):146-9.

12. Lan Z, Hongzhao S, Xiuyu Y, Yang X. Pregnancy outcomes of patients who conceived within 1 year after chemotherapy for gestational trophoblastic tumor: a clinical report of 22 patients. Gynecol Oncol. 2001; 83(1):146-8.

13. Matsui H, Iitsuka Y, Suzuka K, Yamazawa K, Seki K, Sekiya S. Outcome of subsequent pregnancy after treatment for persistent gestational trophoblastic tumour. Hum Reprod. 2002; 17(2):469-72.

14. Blagden SP, Foskett MA, Fisher RA, Short D, Fuller S, Newlands ES, et al. The effect of early pregnancy following chemotherapy on disease relapse and foetal outcome in women treated for gestational trophoblastic tumours. Br J Cancer. 2002; 86(1):26-30.

15. Garner E, Goldstein DP, Berkowitz RS, Wenzel L. Psychosocial and reproductive outcomes of gestational trophoblastic diseases. Best Pract Res Clin Obstet Gynaecol. 2003; 17(6):959-68.

16. Lok CA, van der Houwen C, ten Kate-Booij MJ, van Eijkeren MA, Ansink AC. Pregnancy after EMA/CO for gestational trophoblastic disease: a report from The Netherlands. BJOG. 2003; 110(6):560-6.

17. Matsui H, Iitsuka Y, Suzuka K, Yamazawa K, Tanaka N, Mitsuhashi A, et al. Early pregnancy outcomes after chemotherapy for gestational trophoblastic tumor. J Reprod Med. 2004; 49(7):531-4.

18. Goto S, Ino K, Mitsui T, Kikkawa F, Suzuki T, Nomura S, et al. Survival rates of patients with choriocarcinoma treated with chemotherapy without hysterectomy: effects of anticancer agents on subsequent births. Gynecol Oncol. 2004; 93(2):529-35.

19. Garrett LA, Garner EI, Feltmate CM, Goldstein DP, Berkowitz RS. Subsequent pregnancy outcomes in patients with molar pregnancy and persistent gestational trophoblastic neoplasia. J Reprod Med. 2008; 53(7):481-6.

20. Braga A, Maestá I, Michelin OC, Delmanto LR, Consonni M, Rudge MV, et al. Maternal and perinatal outcomes of first pregnancy after chemotherapy for gestational trophoblastic neoplasia in Brazilian women. Gynecol Oncol. 2009; 112(3):568-71. 
21. Williams J, Short D, Dayal L, Strickland S, Harvey R, Tin T, et al. Effect of early pregnancy following chemotherapy on disease relapse and fetal outcome in women treated for gestational trophoblastic neoplasia. J Reprod Med. 2014; 59(5-6):248-54

22. Vargas R, Barroilhet LM, Esselen K, Diver E, Bernstein M, Goldstein DP, et al. Subsequent pregnancy outcomes after complete and partial molar pregnancy, recurrent molar pregnancy, and gestational trophoblastic neoplasia: an update from the New England Trophoblastic Disease Center. J Reprod Med. 2014; 59(5-6):188-94.
23. Wong JM, Liu D, Lurain JR. Reproductive outcomes after multiagent chemotherapy for high-risk gestational trophoblastic neoplasia. J Reprod Med. 2014; 59(5-6):204-8

24. Sebire NJ, Fisher RA, Foskett M, Rees H, Seckl MJ, Newlands ES. Risk of recurrent hydatidiform mole and subsequent pregnancy outcome following complete or partial hydatidiform molar pregnancy. BJOG. 2003; 110(1):22-6. 